Article

\title{
Current Status of Circular Economy Research in Finland
}

\author{
Aida Hosseinian * D, Jenni Ylä-Mella (D) and Eva Pongrácz (D) \\ Water, Energy and Environmental Engineering Research Unit, Faculty of Technology, University of Oulu, \\ 90014 Oulu, Finland; jenni.yla-mella@oulu.fi (J.Y.-M.); eva.pongracz@oulu.fi (E.P.) \\ * Correspondence: aida.hosseinian@oulu.fi
}

Citation: Hosseinian, A.; Ylä-Mella, J.; Pongrácz, E. Current Status of Circular Economy Research in Finland. Resources 2021, 10, 40. https://doi.org/10.3390/ resources 10050040

Academic Editor: Elena Cristina Rada

Received: 17 March 2021

Accepted: 22 April 2021

Published: 25 April 2021

Publisher's Note: MDPI stays neutral with regard to jurisdictional claims in published maps and institutional affiliations.

Copyright: (C) 2021 by the authors. Licensee MDPI, Basel, Switzerland. This article is an open access article distributed under the terms and conditions of the Creative Commons Attribution (CC BY) license (https:// creativecommons.org/licenses/by/ $4.0 /)$.
Abstract: Circular economy has emerged as a sustainable alternative to the traditional, linear, extractproduce-use-dump economy. The scientific society, practitioners, policymakers, and business sectors are all actively taking part in driving the transition toward circular economy in their own sectors. Every sector is striving to address the environmental issues of their own area, and to find solutions to the problem of resource scarcity. However, there is a lack of comprehensive studies on the general status of circular economy research and applied projects. Finland aims to be a global pioneer in this field, which is why there is a tremendous boost in research in various fields of sustainable materials management. Therefore, there is a need to have a better perspective of the research society's efforts to accelerate the transition to circular economy. The objective of this paper is to review scientific research and practices of circular economy transition in Finland, in order to categorize and analyze them. The paper aims to give an insight into the current status and provide a comprehensive understanding of the trend changes during the past 20 years. The analysis shows that there is growing attention to circular economy in many research fields, researchers and practitioners in all fields have responded to the need of the society. However, the recycling-based 'end-of-pipe' interpretation of circular economy is still more dominant than developing and implementing strategies for circular product design, dematerializing society, and developing service-based business models. It is important to bear in mind that circular economy is about much more than improved resource flows and waste management practices. Achieving a circular economy needs the engagement of the society, it needs invention and innovation and it also requires the creation of new technologies, products, services, and business models. This study gives a comprehensive perspective at the national level and addresses the key actions and sectors which require more investment and attention from the scientific community to boost the transition toward circular economy. There are some limitation in this study derived from the method of data collection and selection of databases. Due to this, there may be valuable works that were not published, or only in the Finnish language and were, therefore, not identified in this study.

Keywords: circular economy; scientific research; research trend analysis; Finland

\section{Introduction}

With each passing year, as the climate is changing and the average atmospheric temperature is rising, there is a risk of extinction for almost $12 \%$ of species on the planet. At the same time, pollution and acidification of oceans are increasing and forests are being destroyed [1-3]. Over the past decade, the growing awareness of environmental issues has attracted interests in circular economy, which aims to provide a better alternatives to linear economic models. Circular economy is habitually understood as the act of turning wastes into resources. This limited, end-of-pipe perspective may lead to the failure of circular economy, since reuse, repair, and options fell out of this frame. Moreover, some alternatives such as green chemistry or biotechnology may lead to more expensive solutions and higher environmental impacts [4]. Circular economy implementation is a challenging task since the structures in economy and societies have been set to linear. As well, it shall not be neglected that sustainability patterns require both innovative concepts and 
actors at the same time $[4,5]$. There are many challenges, barriers, obstacles, as well as opportunities, benefits, and advantages in the way of transition toward circular economy. Overall, circular economy is a promising concept since it has attracted the attention of the business community as a move toward sustainable development [6].

The Transition Pathways Towards Circular Economy (TRANSCIRC) project funded by the Academy of Finland (nro. 310405) responds to the challenges of sustainable use of natural resources and resource scarcity by producing pathways that enhance transition towards a circular economy in Finland within the global context. The target of the project is to identify the current challenges of implementing circular economy and to create a future-oriented solution for overcoming the challenges in the way. Work package 1 had the goal of gaining an overview of the present situation of circular economy in Finland, by evaluating how the perspective and principles of circular economy have been taken into account at the national level. There were three research questions to be answered in work package 1 of this project:

1. Current state and trends of resource-efficient circular economy

2. Overall barriers and drivers for the future development of circular economy

3. Identification of potential key sectors, activities, and materials

The goal of circular economy, decoupling economic growth from environmental pressure, is going to be carried out within different policies, legislations, voluntary agreements, and investments in European Union and in the national levels. However, the scientific assessment of the transition has not been comprehensive in every EU Member State at the national level. There is a necessity for countries to recognize key sectors and priority streams to set goals and monitor progress. The present article provides an overview of the studies, researches, and projects that have been done in Finland in the context of circular economy, to identify strategic focus areas and research gaps.

Moreover, this study analyzes whether the scientific and practitioner society are addressing the key elements of the transition toward circular economy. The analysis has been carried out at the national level and based on the policy priorities and societal need of Finland. It also investigates how the trends of research have been changed during the last 20 years in the most critical areas. This study aims to highlight the gaps in circular economy research and see how legislations inform circular economy research focus. For this purpose, we reviewed circular economy studies and projects and analyzed them side-by-side with correspondent policies to assess key drivers of circular economy research focus.

The following section is the summary of the European Union and Finnish policies on circular economy. The TRANSCIRC project hypothesizes that, in order to boost the transition, new policy measures and tools are required. Therefore, to assess the impact of policies and regulation on the research trends, a policy timeline has been created in the next section. The policy timeline is followed by methodology and details of the analysis applied and, subsequently, results and discussion are provided. Furthermore, the focus of research and its correlation with these policies has been studied. It is safe to expect that new policies and strategies will result in growing attention in all aspects of circular economy research. However, it is not clear which subjects have received more attention and where there is still lack of research. This paper aims to identify what areas have captured the interest of research society and whether there are crucial aspects of circular economy that have not received sufficient attention.

\section{Policy Timeline in Europe and Finland}

The movement toward circular economy has accomplished many achievements, the indication is that the goals have been met with great enthusiasm; however, the European Commission acknowledges that there is more to do. Therefore, legislation, regulations, and policies have evolved continuously to support the transition toward circular economy. The most recent EU policy tools aim at protecting the environment and human health, providing more energy and resource-efficient products and empowering customers to choose more sustainable products [2]. In this context, a policy timeline is presented in 
Figure 1 illustrating EU policies on circular economy as well as Finnish National legislation, roadmaps, policy targets, driving economic actors through a systematic change to achieve the benefits of circular economy.

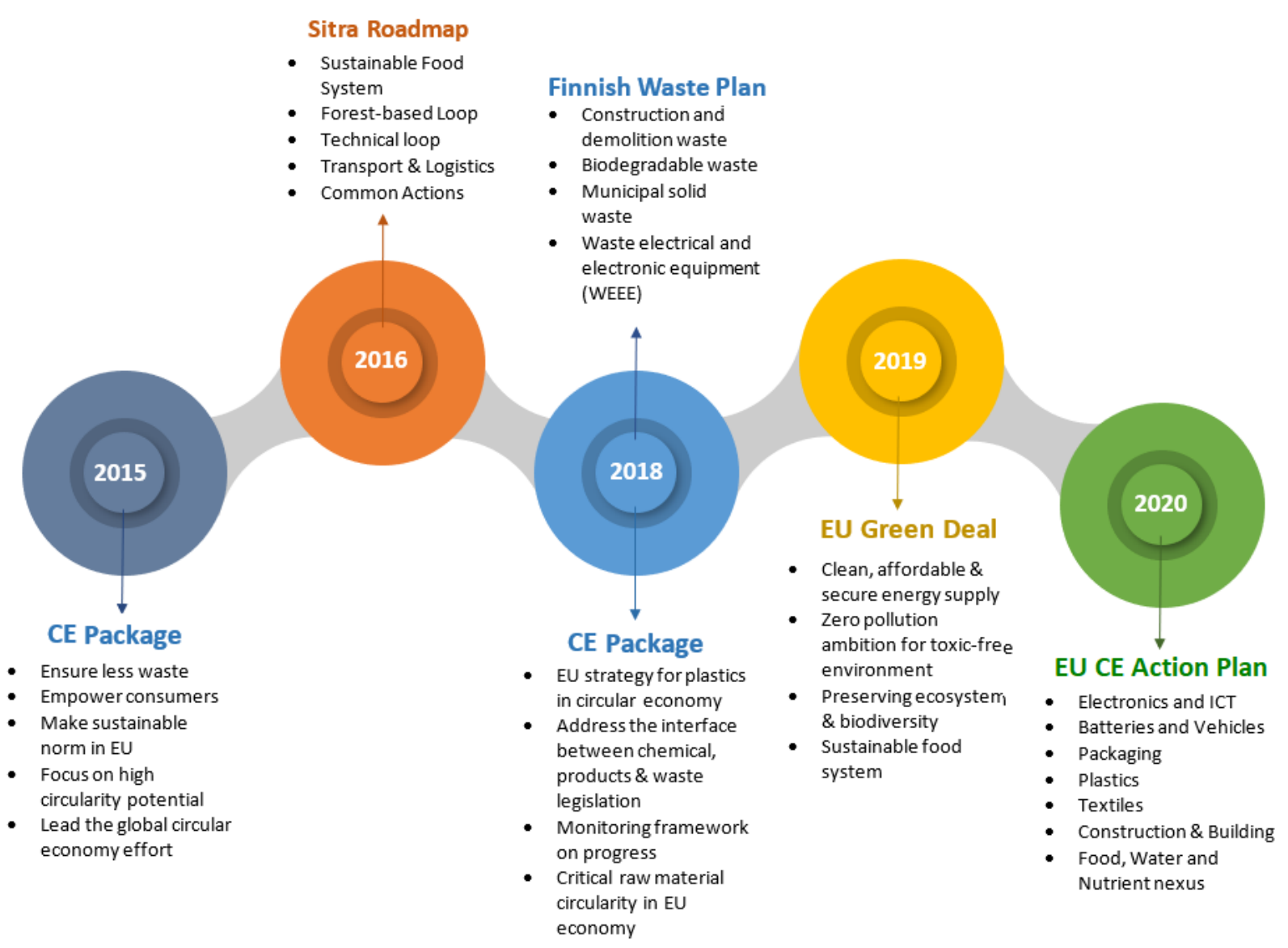

Figure 1. Circular economy (CE) policy timeline 2015-2020 in European Union level and Finland.

\subsection{Circular Economy Package 2015}

The first circular economy package was launched in 2015 and it included an action plan, a list of follow-up initiatives, and four legislative proposals on waste. It had four key action areas to achieve the transition toward circular economy: production, consumption, waste management, and secondary raw materials. The action plans in this package had set the goals for the entire lifecycle of the products and introduced legislative and nonlegislative measures in target areas such as landfill, reuse, and recycling to be met by 2030 [7].

\subsection{Finnish Roadmap to Circular Economy 2016}

Finland has a great opportunity to create a successful carbon-neutral and sustainable society through circular economy. The government's goal is to be the global forerunner in circular economy by 2050, the key objectives of the government are bio-economy and clean, carbon-neutral, and renewable energy [8]. Being the first nationwide plan in the world, the Finnish Innovation Fund Sitra, ministries, and related stakeholders, published the Finnish roadmap to circular economy. The actions of the roadmap were divided into three categories: administrative requirement and policy, key focus area, and focus area pilots. The roadmap identified five areas the transition to start and grows from (Figure 2): sustainable food system, forest-based loops, technical loops, transport and logistics, and common actions [9]. 


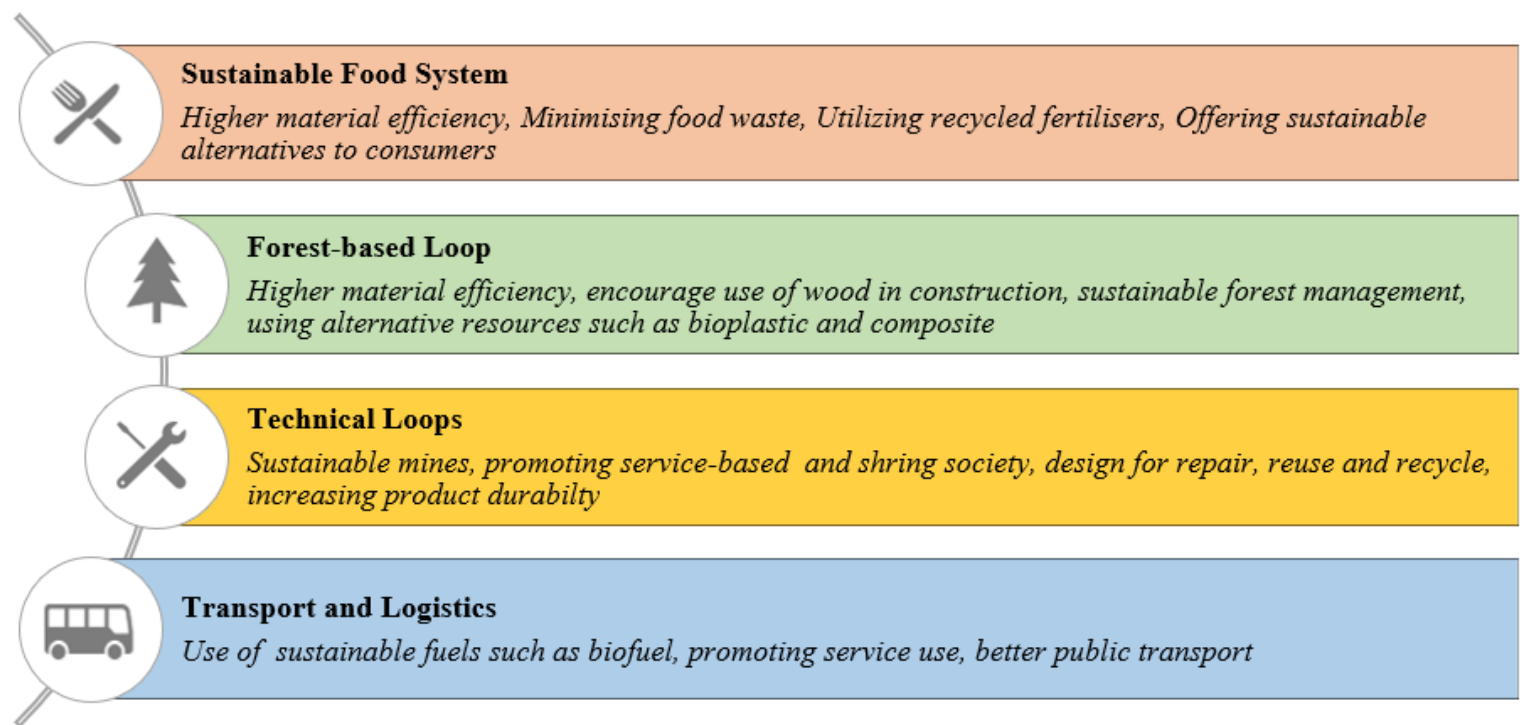

Figure 2. Focus areas and targets of Sitra's roadmap to circular economy 2016.

'Sustainable food system' has the goal of making Finland a global exporter of solutions regarding sustainability in food systems and the following key policy actions were introduced for it: the creation of a market for organic recycled nutrients, minimization of food waste, and supporting biogas system.

'Forest-based loop' has the key policy for making Finland the leader in circular bioeconomy through the strategy of national forest industries. To this end, the tools are: maximizing the overall value of Finnish forest-based products and services, encouraging public procurement to select wood-based product and products with a lower environmental impact, supporting investments in bio-product and bio-service demonstration; and encouraging the development of Finish wooden furniture and construction.

'Technological loops' take into account sustainability of material use and products, optimization of products' lifespan, and promoting reuse. This is to be achieved by these key policies: encouraging the use of secondary raw materials, using side streams and by-products, and eco-design requirements in different stages of production processes.

'Transport and logistics' aims at developing smart transport to a fossil-free direction, and the key policies focus on accelerating the change toward a more service-based transportation system.

'Common actions' create an operating system, which encourages and promotes systematic change for circular economy.

\subsection{Finnish National Waste Plan 2018}

The Finish National Waste Plan sets out objectives for waste management and waste prevention and it is titled "From Recycling to Circular Economy". There are four key waste streams identified in this plan, and they were selected due to the fact that their quantities have been increasing and/or may contain harmful substances. These four waste streams are:

i. Construction and demolition waste

ii. Biodegradable waste

iii. Municipal solid waste

iv. Waste electrical and electronic equipment (WEEE)

The Finnish National Waste Plan sets the targets for 2030 and will be in effect until 2023 [10]. 


\subsection{Circular Economy Package 2018}

Three years after the adoption of the first circular economy package, the European Commission published a comprehensive report on the 54 actions that had been delivered, and an analysis on how circular economy had been implemented, the achievements, and the challenges. Following the report, the next circular economy package has been launched in 2018, consisting of:

- EU strategy for plastics in circular economy with the aim of transforming plastic product design, production process, use, and recycling [11].

- Communication to assess the relationship between chemical, product and waste legislation, how some chemicals can hinder reuse and recycling and, therefore, the transition toward circular economy [12].

- Monitoring framework with a set of ten key indicators to assess the progress of transition toward circular economy in each phase of resources, products and services life cycle in this package. These ten key indicators are selected in a way that they capture the main elements of a circular economy and provide a wide perspective of key leverage points to increase the circularity in the European economy [13].

- Report on critical raw material in the circular economy and the potentials of more circular usage of the 27 critical raw materials in the economy [14].

\subsection{The European Green Deal 2019}

The European Green Deal provides a roadmap to improve the efficiency in resource usage, restore biodiversity, reducing pollution, and the outlines the investments needed for transition toward a climate neutral Europe by 2050. To reach the goals of the European Green Deal, different actions are needed such as clean energy policies across different sectors, investments in environmentally friendly technologies, a society supporting innovation, decarbonization of the energy sector, and higher building energy efficiency. In general, the European Green Deal aims to transform European economy into a sustainable future, through financing the transition, mobilizing research, and fostering innovation [3].

\subsection{The Circular Economy Action Plan 2020}

Closing the loop is the most current circular economy policy objective in the EU, which guides the transition to circular economy with generating new and sustainable competitive advantages. The proposals for circular economy action plan 2020 focus on consumption changes and production behavior through reuse and recycling, as well as waste management [15]. Several measures have been presented in the latest action plan to ensure transition acceleration, such as making sustainable product the norm in the EU, focusing on high potential sectors for circularity, decreasing the amount of waste, and leading the global movement toward circular economy.

In this future-oriented agenda, with the ultimate goal of cleaner and more competitive Europe, a variety of organs such as economic actors, consumers, citizens, and civil society organizations are seen as co-creators of its action plan. The 2020 action plan target is accelerating the transition needed by European Green Deal. It ensures that European regulation is well recognized and updated for sustainable future, different sectors take full advantage of new opportunities and people and businesses have the lowest burdens on their shoulders. The 2020 Action Plan emphases product policy sustainability by promoting sustainable product design, empowering consumers and public buyers, and by making production processes more circular. The key product value chains, which require urgent and comprehensive actions were identified as follows [15]:

- Electronics and ICT

- Batteries and vehicles

- Packaging

- Plastics

- Textiles

- Construction and buildings 
- $\quad$ Food, water, and nutrients

\section{Methodology}

This article analyzes studies, programs, and projects that have been done within the topic of circular economy in Finland, during the past 20 years. The study was performed for two time periods: The first phase is the period of 2000-2016, and in second one for 2017-2020. The analysis between 2000 and 2016 was done at the beginning of the TRANSCIRC project, in order to evaluate the status of circular economy research in Finland at that time. At the same time, Sitra's roadmap to circular economy was published, which is the first world's national roadmap to circular economy and identified the critical sectors in Finland. To investigate, how the Sitra roadmap has affected circular economy research in Finland, a second analysis has been carried out for 2017-2020.

In this context, the organizations, companies, and universities in Finland carrying out circular economy research, studies (including BSc, MSc, and Ph.D. theses) and projects have been identified, and their activity reviewed by browsing their webpages and keyword searches in Science Direct and Scopus. Compiling data from Science Direct and Scopus databases has been done based on a combined method of quantitative analysis and trend analysis [16] where the selected terms were contained in the title, abstract, and keywords and published during the two mentioned periods of time. Furthermore, the affiliation of the authors has been included in the search criteria for the two mentioned databases. Figure 3 shows the approach of the study analysis. The analysis in the Scopus webpage also has been used to get a deeper knowledge of the trend changes over the time and investigate which topics are in more focus for research in Finland.

Step 1 - Analysing the researches done during $2000 \_2016$

Figure 3. The approach to analyze the studies carried out in Finland.

Similar reviews of circular economy research have been performed before, using different methods, such as bibliographic analysis, cluster analysis, network analysis, etc. [17-20]. The novelty of our research is that it is a comprehensive national level study, which reviews all researches done in Finland during the selected period, including also applied project. We assert that national level studies are essential, in order to recognize key sectors and priority streams critical for circular economy. For example in the EU, Member State should make efforts to recognize relevant sectors or streams, which may not be listed as priority at the EU level. Our goal was to recognize gaps and highlight topics that require more emphasis by the research society, in order to boost the transition toward circular economy.

We included in our investigation journal papers, conference papers, review articles, book chapters, technical notes and reports that have been carried out in Finland, or if at least one of the authors' affiliation is Finland. For a part of the analysis, only journal papers have been taken into account; where one of the selected topics has been examined during the study period. This allowed focusing more on higher impact research since, usually, journal articles require more rigorous scientific investigation than conference papers or project reports [21]. Additionally, in order to get a better perspective of the research trends, the number of research (research/project) per year and their increase rate was used. 
To extract data from Science Direct and Scopus, several search keywords have been used. Subsequently, researches have been classified based on the following key information: studies/project author(s), the title of publication, date of publication, objective of the study, publisher for articles/financier or partner for projects. Duplicates of articles that were found in multiple databases have been removed. The second step was to divide selected studies into categories; for this purpose, the priority areas of the reviewed policies in the introduction section have been selected (selection references in Table 1). Furthermore, some categories were added to the list based on the high interest of research society and a high number of the articles found during this study (such as microplastics). All categories, selection references, and search keywords have been listed in Table 1.

Table 1. Categories, their selection references, and search keyword.

\begin{tabular}{|c|c|c|}
\hline Category & Selection References & Search Keywords \\
\hline Circular Economy Concept & $\begin{array}{l}\text { Circular Economy package 2018, Sitra } \\
\text { Roadmap 2016, Finnish waste plan 2018, }\end{array}$ & Circular AND Economy \\
\hline Energy from Waste & European Green Deal 2019 & $\begin{array}{c}\text { Waste AND Energy } \\
\text { Waste AND Incineration OR Combustion }\end{array}$ \\
\hline Bio-treatment and Biogas & Finnish Waste Plan 2018 & $\begin{array}{c}\text { Biotreatment AND Waste } \\
\text { Biogas }\end{array}$ \\
\hline Municipal Solid Waste (MSW) & Finnish Waste Plan 2018 & $\begin{array}{c}\text { Municipal AND Solid AND Waste } \\
\text { MSW }\end{array}$ \\
\hline Plastic Waste & $\begin{array}{l}\text { Circular Economy package 2018, } \\
\text { European Action Plan } 2020\end{array}$ & Plastic AND Waste \\
\hline Industrial Waste & $\begin{array}{c}\text { Sitra Roadmap 2016, European Action } \\
\text { Plan } 2020\end{array}$ & $\begin{array}{c}\text { Industrial AND Waste OR Byproduct OR } \\
\text { Sidestream }\end{array}$ \\
\hline Waste Electrical and Electronic & European Action Plan 2020, Finnish & Electronic AND Waste \\
\hline Equipment (WEEE) & Waste Plan 2018 & Electrical AND Waste \\
\hline Nuclear and Hazardous Waste & European Green Deal 2019 & Nuclear OR Hazardous AND Waste \\
\hline Food Waste & $\begin{array}{l}\text { Sitra Roadmap 2016, European Green } \\
\text { Deal 2019, European Action Plan } 2020\end{array}$ & Food AND Waste \\
\hline Fertilizer from Waste & European Action Plan 2020 & Biofertilizer OR Fertilizer AND Waste \\
\hline Biomass and Wood Waste & Sitra Roadmap 2016 & Biomass OR Wood AND Waste \\
\hline Construction and Demolition Waste & $\begin{array}{c}\text { European Action Plan 2020, Finnish } \\
\text { Waste Plan } 2018\end{array}$ & Construction OR Demolition AND Waste \\
\hline Metal and Mining Waste & Sitra Roadmap 2016 & $\begin{array}{l}\text { Mine AND Tailing } \\
\text { Mine OR Metal AND Waste }\end{array}$ \\
\hline Microplastics & European Green Deal 2019 & Microplastic \\
\hline Waste Management & Circular Economy package 2018 & $\begin{array}{l}\text { Waste AND Management } \\
\text { Reuse }\end{array}$ \\
\hline Reuse and Remanufacture & $\begin{array}{c}\text { European Green Deal 2019, European } \\
\text { Action Plan } 2020\end{array}$ & $\begin{array}{c}\text { Remanufacture } \\
\text { Refurbish } \\
\text { Repair }\end{array}$ \\
\hline Critical Raw Material & $\begin{array}{c}\text { Circular Economy package 2018, Finnish } \\
\text { Waste Plan } 2018\end{array}$ & Critical AND Raw AND Material \\
\hline Textile Waste & European Action Plan 2020 & Textile AND Waste \\
\hline Sharing Economy & $\begin{array}{c}\text { European Green Deal 2019, European } \\
\text { Action Plan } 2020\end{array}$ & Service-based OR Sharing AND Economy \\
\hline Eco-design & European Green Deal 2019 & Ecodesign \\
\hline
\end{tabular}

In the third step, the first two steps were repeated, to identify the research outputs during the 2017-2020 period. With these results, comparisons between these two periods were possible; moreover, a trend change analysis was carried out in the fourth step. By summarizing results from previous steps, the overall status of circular economy studies and researches in Finland was established. 


\section{Results and Discussion}

After categorizing the researches/projects in selected groups described in Table 1, the total number of research (research/project) for each topic has been listed in Table 2. The average number of research is shown in Figure 4 for both periods where the numbers have been divided by the length of periods to make the comparison easier.

Table 2. Total number of researches / projects for all categories in the year 2000-2017 and 2017-2020 in Finland.

\begin{tabular}{ccccc}
\hline & Category & Year 2000-2016 & Year 2017-2020 & Increase \%/Year \\
\hline 1 & Microplastics & 3 & 34 & 4433 \\
2 & Critical Raw Material & 26 & 26 & 300 \\
3 & Circular Economy Concept & 29 & 281 & 3776 \\
4 & Eco-design & 38 & 46 & 384 \\
5 & Textile Waste & 41 & 25 & 144 \\
6 & Sharing Economy & 51 & 90 & 606 \\
7 & Plastic Waste & 109 & 304 \\
8 & Fertilizer from Waste & 61 & 97 & 238 \\
9 & WEEE & 96 & 82 & 112 \\
10 & Municipal Solid Waste & 97 & 64 & 84 \\
11 & Food Waste & 121 & 76 & 191 \\
12 & Biotreatment and Biogas & 165 & 94 & 89 \\
13 & Construction and Demolition & 165 & 120 & 52 \\
14 & Nuclear and Hazardous Waste & 199 & 376 & 186 \\
15 & Metal and Mining Waste & 500 & 358 & 60 \\
16 & Industrial Waste & 594 & 237 & 80 \\
17 & Waste Management & 858 & 386 & 91 \\
18 & Energy from Waste & 869 & 414 & 50 \\
19 & Reuse, Repair and & 1101 & 412 & 9 \\
20 & Remanufacture & 4023 & 1099 & \\
\hline
\end{tabular}

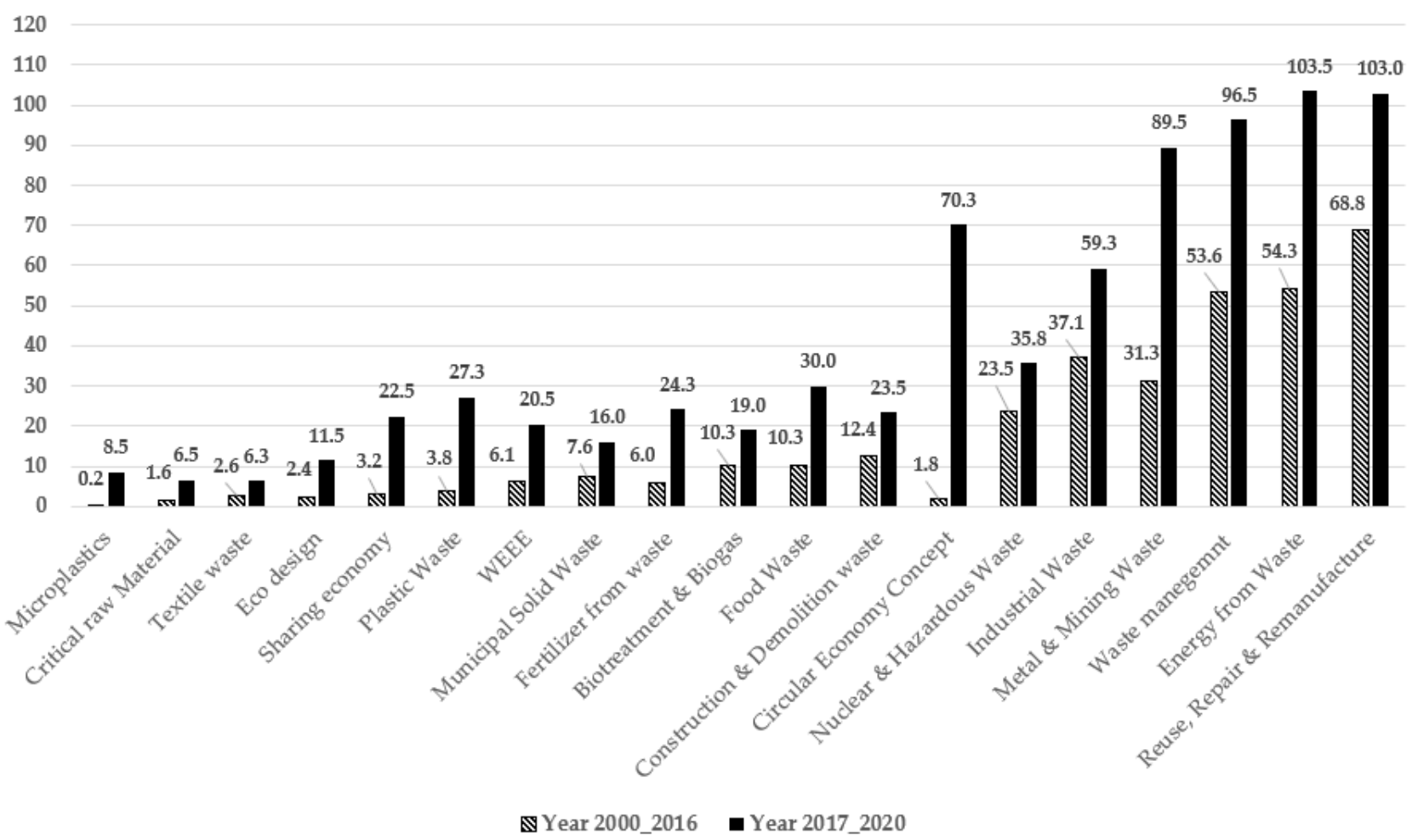

Figure 4. Average number of researches/projects per year for period 2000-2016 and 2017-2020 for all categories except for biomass and wood waste (for biomass and wood waste $n=251$ for 2000-2016 and 275 for 2017-2020). 
In both periods, the highest number of researches was on biomass and wood waste, which is due to the fact that forest industries including paper and pulp industries are one of the most important industrial sectors in the Finnish economy. Furthermore, one of the key policies for making Finland the leader in circular bio-economy is through forest industries [9]. The combination of environmental awareness, economic drivers, and global and regional policies is responsible for incentives in moving toward circular forest industries. The forest industries aim to maintain their leading position in global markets by ensuring product competitiveness and highly efficient processes, and promoting the substitution of traditional (fossil-based) materials with renewable raw material [22,23]. Consequently, the number of the research papers in this field are the highest among all the categories; in the first period there were 4023 papers ( 251 research/year) and, in the second period, there were 1099 papers (274 research/year) written on these topics.

In the 2000-2016 period, the most popular topic of research after biomass and wood waste was reuse, repair, and remanufacture, energy from waste, waste management, industrial waste, and metal and mining waste, respectively. Where in the 2017-2020 period energy from waste, reuse, repair and remanufacture, waste management, and metal and mining waste were the topics of the highest interest. The topics with the highest increase rate are micro-plastics, circular economy concept, plastic waste, sharing economy, and eco-design. A summary of the average number of researches/year for all categories in periods 2000-2016 and 2017-2020 is shown in Figure 4. The wood and biomass researches, however, have been omitted from this figure for better scaling.

Research on the circular economy concept shows an enormous increase rate (3776\%) among all other categories, with an increase in the average number of research/year from 1.8 in the first period to 70.3 in the second period. The first circular economy package has been launched in 2015 and the Finnish roadmap to circular economy has been published in 2016 by Sitra, which led to a high increase in popularity of these topics in the second period. Up to the year 2016, the total number of journal publications on this topic was less than 10 and it started rising from 20 research in 2016 to 95 in 2019 (Figure 5). In general, the number of researches found in the field of circular economy concept shows a rapid increase among both academic society and practical projects [24] and Finland is among the top 10 countries publishing in this field. Figure 6 shows the countries with the highest number of publication in this topic.

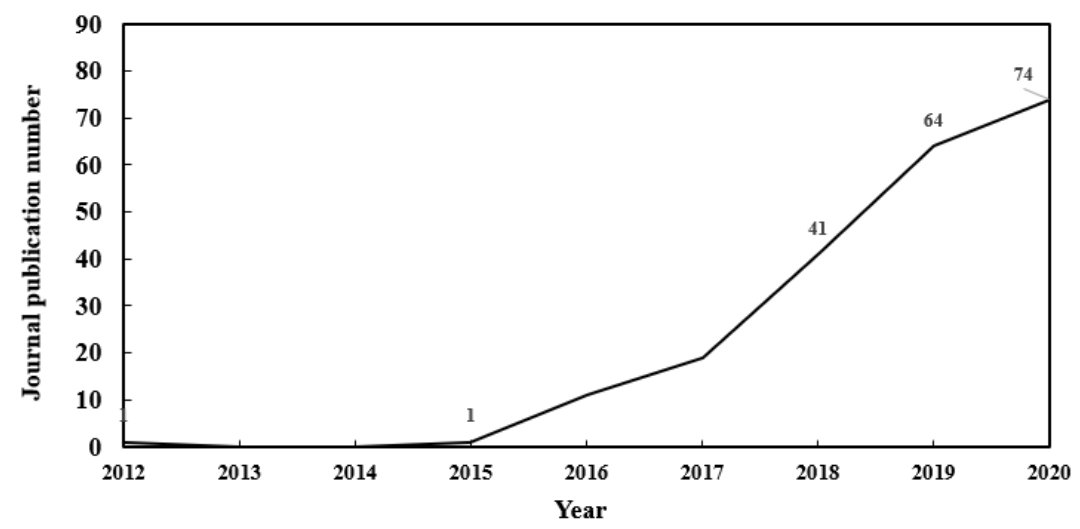

Figure 5. Circular economy concept journal publications in Finland during 2000-2020 (the first article has been published in 2012). 


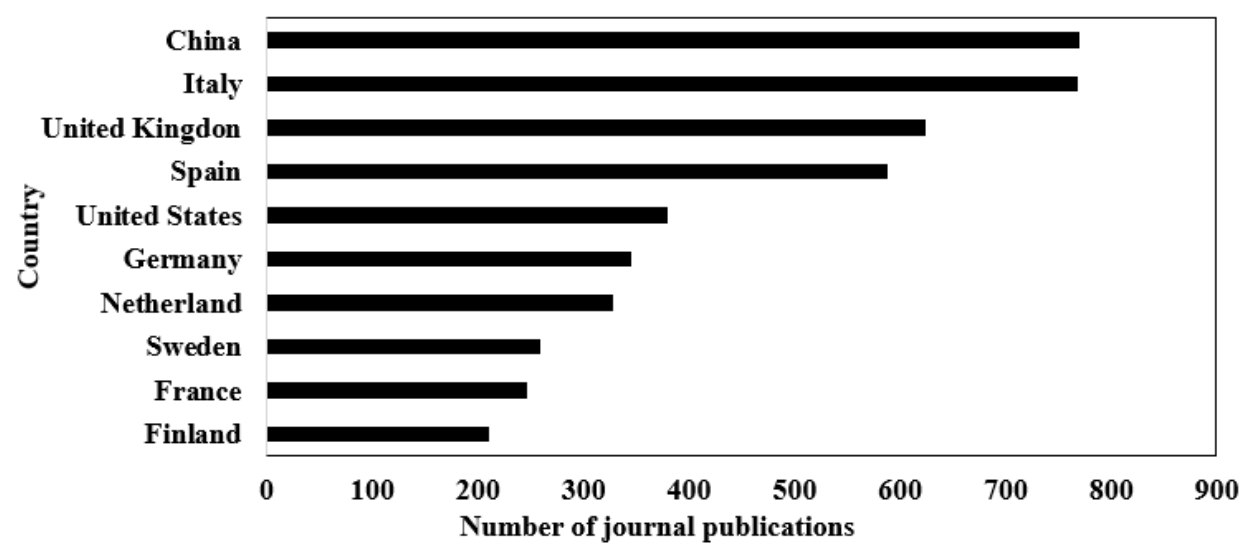

Figure 6. Circular economy journal publications worldwide during 2000-2020.

However, the definition of circular economy concept has various interpreting by different researchers and include a broad spectrum of understanding. In 2015, researchers refer to circular economy as 3R principles: Reduction, Reuse and Recycle [4,25-27]. However, in the more recent and most cited publication [24], authors refer to circular economy as 9R: Refuse, Rethink, Reduce, Reuse, Repair, Refurbish, Remanufacture, Repurpose, Recycle and Recover based on the policy report on circular economy by Netherlands environmental agency [28]. In the most cited publication on this topic in Finland [6], a definition for circular economy is provided as "an economy constructed from societal production-consumption systems that maximize the service produced from the linear nature-society-nature material and energy throughput flow".

In contrast with the definition of circular economy, when reviewing the published articles in Finland it is evident that the majority of the research and projects seem to investigate end-of-life issues such as waste collection, recycling, and resource recovery, rather than focusing on the concepts such as rethinking and re-establishing the business models to a more sustainable and environmental friendly systems. In circular economy, solutions shall focus primarily on keeping products and parts in the inner circle of the economy and reusing products and components. Breaking down products at the end of their useful life and bringing their material content back to new material loops is the next highest objective. To this end, product design is one of the key enablers, when it focuses on designing durable products that can be repaired, shared, reused, and remanufactured. The role of repair/reuse/remanufacture and service-based economy has been emphasized within circular economy policies, which call for a shift in mindset as well as a need for more investigation to support this objective.

In this essence, the three topics: (1) reuse, repair, and remanufacture, (2) sharing economy, and (3) eco-design are the top priorities of the newest EU policies. Looking at the number of reuse, repair, and remanufacture researches done in the two periods, this topic has among the highest number of publications in both periods and it shows a slight increase in the number of research/year in the second period. Sharing economy has experienced high increase rate in the second period (606\%); however, the number of researches found is still below 100. Eco-design has been among the least favored topic with the low number of researches in the first and second period; even though it has a high increase rate, the total number of researches in this topic is less than 100 in total.

Waste management has been in the center of attention in both periods, in the first period there were approximately 54 researches/year on this topic and in the second period 96 (almost doubled). The amount of waste produced in the EU is five tons per capita annually [15]; therefore, it is no surprise that this subject is among the top five favorite areas of research in both periods. Decoupling economic growth from waste generation needs significant effort in various aspects, including waste management policies, business models, and product designs. This makes it clear why there are high efforts in enhancing waste policies, in order to prevent waste, increase circularity, promote a toxic-free environment, 
developing a functional EU market for secondary raw materials and addressing waste exports from the EU $[15,29]$.

Metal and mining waste topic with high increase rate of $186 \%$ gained a place among the top five topics with biggest research/year in the second period. Sitra's roadmap to circular economy in Finland has set a clear target for mines as a primary sector in the technical loop to minimize their environmental impact, use non-renewable resources sustainably and utilize their side stream [9]. Exhaustion of metal ore deposits leads to the situation that large amounts of tailings, sludges, slags, dust, and ashes from metallurgical processes and mining industries could be categorized as secondary raw material, containing not only base metals, but also critical raw materials [30]. Consequently, the interest in this topic has been raising globally [31] and researchers and practitioners in Finland have also shown interest in sustainable metal and mining processes and move toward zero-waste and closed-loop thinking in mining and metallurgy.

Further to announcing the list of critical raw material by the European Commission [32], research on coupling mining waste management with critical raw material recovery has increased from 14 in 2011 to 30 in 2020. Critical raw materials are present in a wide range of products in relatively small quantities but their vital functionality gives a high value to them [33]. Recycling of critical raw materials should be of high priority, still, this subject is the second least published in Finland (52 in total). However, the trends show that the interest in this subject has been constantly increasing during the last 20 years.

Microplastics and plastic waste are among the topics with the highest increase in interest rate (microplastic with $4433 \%$ is the highest increase rate among all topics and plastic waste with $615 \%$ increase rate is the third highest). Management of plastic waste is improving in the EU; however, large amounts of plastic waste in the EU are still going for landfill (31\%) or incineration (39\%) [11]. Therefore, the first European strategy for plastics in circular economy has been adopted in 2018 to transform design, use, production, and recycling of plastics in the European Union [11]. High possibility of dangerous impacts of plastic waste in different environments of life such as marine environment, freshwater ecosystem, soil, and food chain especially marine environment contamination made this topic popular among scholars and practitioners [34]. Figure 7 shows the increasing interest in this topic during the last two decades. Microplastic pollution also contributed to the increase in the amount of interest in this topic. Microplastics, which have been recognized as a risk to marine life globally and also in Finland in recent years, have been increasingly in the focus of scientific research, since microplastics have been found even in Arctic and Antarctic waters [35]. This lead to an exponentially increase in scientific studies in this field [36]. In this study, number of research/year about microplastics shows 14 times more in the 2017-2020 period in Finland, which shows the heightened attention on this topic, whereas in the first period the least amounts of publications were about microplastics.

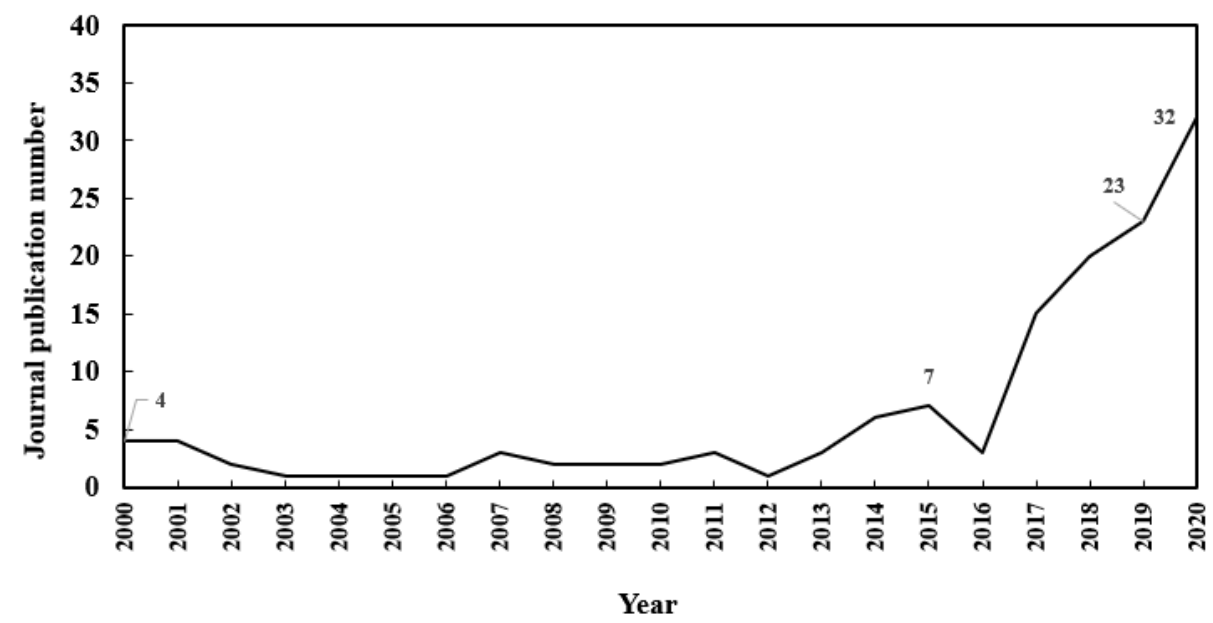

Figure 7. Plastic waste journal publication in Finland during 2000-2020. 
Food waste is one of the priority areas of circular economy action plan 2020 and a huge concern in terms of food security and eradicating poverty and hunger in the coming decades. Furthermore, food waste, which accounts to approximately one-third of global food supply also has a significant effect on freshwater quality, greenhouse gas emissions, soil and cropland degradation, and increase in fertilizer usage $[37,38]$. These concerns have led to a constant increase in the number of publications on this topic from 2000 to 2020, as illustrated in Figure 8. In Finland, the amount of food waste is around 130 million kg each year that is $23 \mathrm{~kg}$ per capita/year from the household sector. Moreover, if food waste from restaurants and food industries is taken into account, the total number is $62-86 \mathrm{~kg}$ per capita/year, adding up to 335-460 million $\mathrm{kg}$ of food waste in year. It contributes to over one-third of Finnish consumption's impact on the environment and, due to eutrophication, and the impact on the water system is even more pronounced $[39,40]$. Therefore, the interests of practitioners and scholars in the reduction of food waste on both micro- and macroeconomic levels have increased during this 20-year period. However, most of the transition movements in this section focus on downstream approaches. It should be noted that, although the transition should be throughout the food chain, changes would be more effective on upstream and niche levels [41,42]. Food waste and food loss happens in all stages of the food chain; from food production, through storage, transportation, retail, food preparation, consumption, and food waste management. Therefore, circular economy shall influence all stages and not only address the last one [42]. Consequently, it is essential to pay more attention to food waste prevention and fill the research gaps in this field. Policies should emphasize and show stronger interest to favor the food waste prevention agenda.

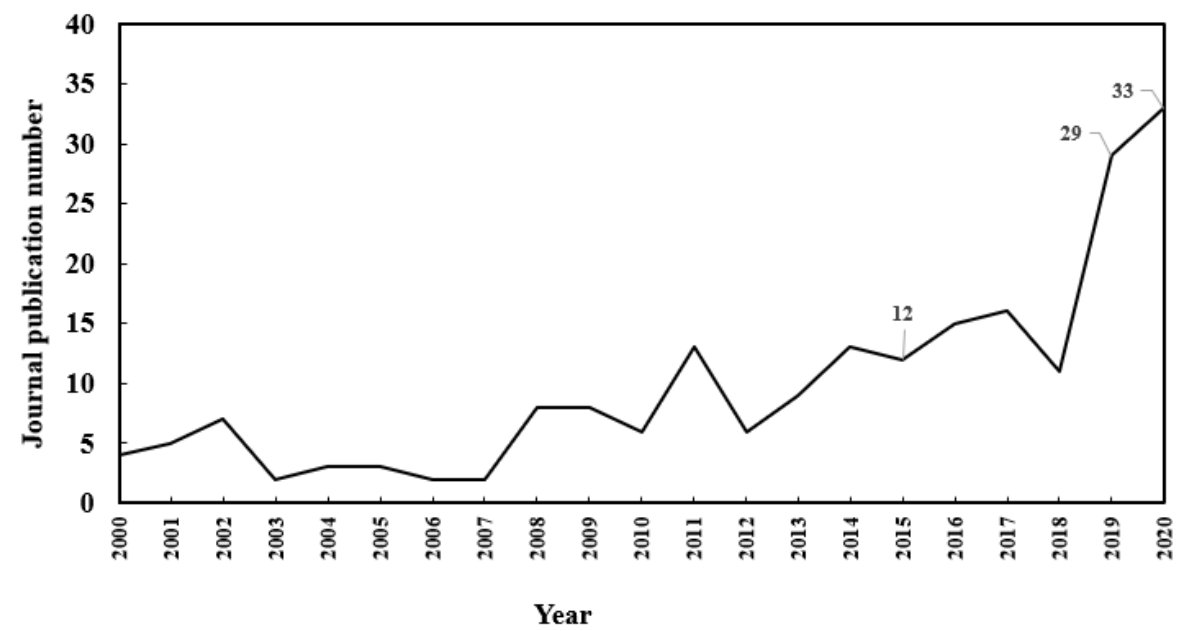

Figure 8. Food waste publications in Finland during 2000-2020.

In this context, recovery and recycling of nutrients from waste, which is in ties with food-nutrient-water nexus, is a hot topic in environmental studies. Nutrient recovery and recycling have various routes such as wastewater treatment, biomass/bio-waste anaerobic digestion, composting, biological treatment, and incineration [43-46]. Phosphorus (P), Nitrogen $(\mathrm{N})$, and Potassium $(\mathrm{K})$ are the three main nutrients used in fertilizers, among these three, $\mathrm{P}$ is the most crucial since it is non-renewable and it is one of the critical raw material elements [32]. Therefore, numerous studies have been done on P recovery and recycling methods from a variety of waste sources. The trend shows an increasing interest in this topic also among the Finnish scientific community and practitioners, along their global peers.

The numbers of journal publications in each field during 2000-2020 in Finland show how policy focus and societal needs have influenced researchers to inspired them to invest in a specific topic. Figure 9 summarizes the trends of six categories to make it easier to assess the trends and compare the research attention in different fields. It also indicates that the volumes of wastes have an undeniable impact on influencing research interests. The 
first circular economy package, which was launched in 2015, had influenced the increased rate of almost all of the subjects and the second circular economy package has increased the interest even more. However, clearly, some of the subjects have received less interest, and these subjects have seen neither dramatic growth, nor a high total number. For instance, sharing economy which is one of the key actions of transition toward circular economy has not been well studied, interest picked up only after 2016, but still not very relevant compared to other subjects. The same trend can be observed for fertilizers from waste; the total number of journal publications found on this topic during the last two decades is 111 . It is one of biggest increase rates in the second period, yet the numbers of publications on this topic are still very low compared to other subjects. Research in food and plastic wastes shows a constant and steady increase during the entire study period but there is a noticeable jump in 2018 for both categories. The first European Plastic strategy has been adopted in 2018 and food waste is a key focus area of the most recent circular economy policies, which may have influenced the interests in these two fields.

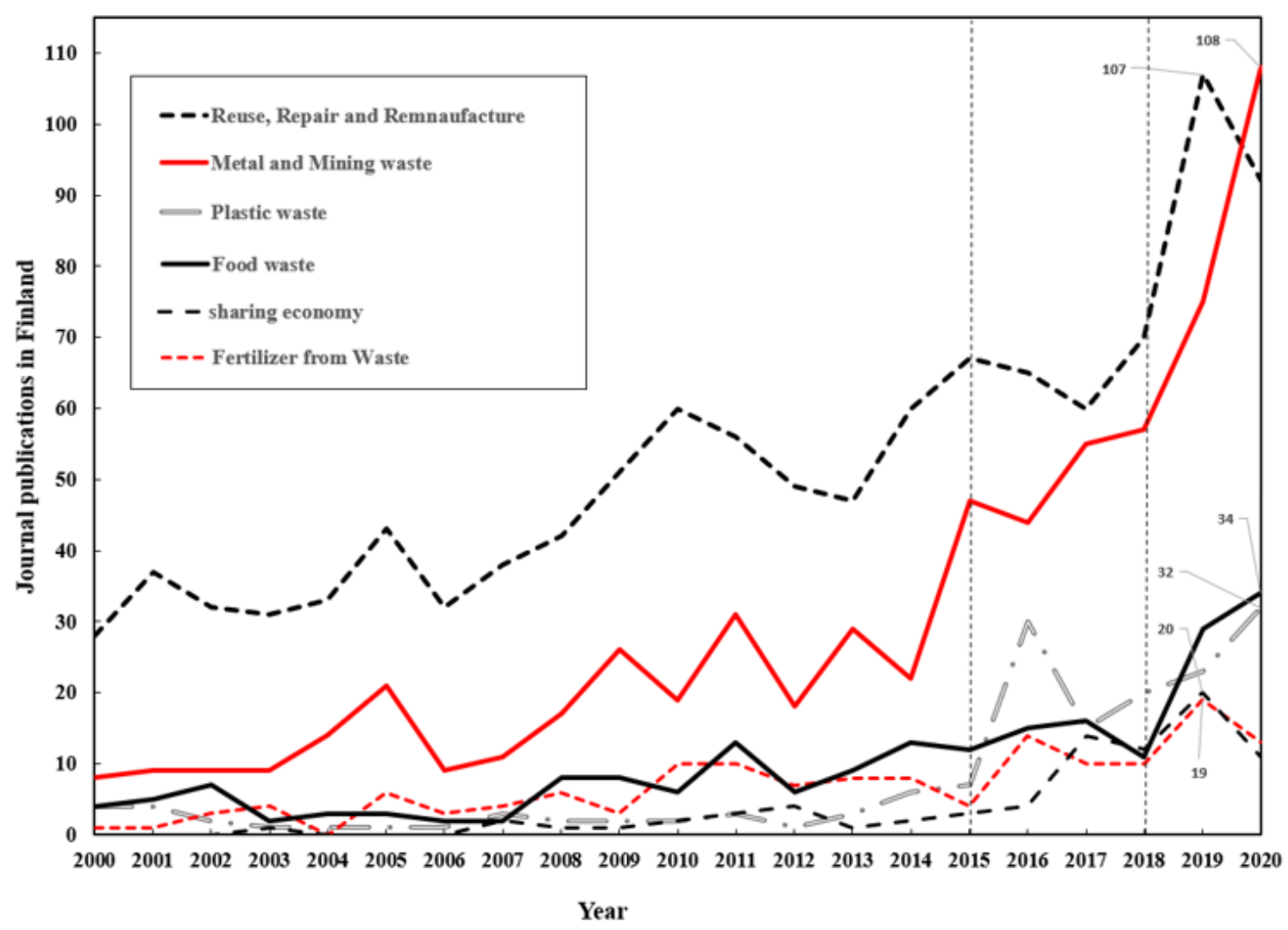

Figure 9. Summary chart of publications in Finland during 2000-2020 by topic for six categories. Dashed lines indicate the publication years of Circular economy packages.

Finally, it can be mentioned that the most popular journals to publish topics related to circular economy concept are: Journal of Cleaner Production, Sustainability, Resources Conservation and Recycling, Waste Management, Smart Innovation Systems, and Technology, and Procedia CIRP.

\section{Conclusions}

Circular economy has been high on the political agenda in the recent years. Circular economy aims at keeping products and materials at their maximum value and functionality, with the aspiration of reducing wastage and pollution and supporting a regenerative economic system. The starting point is to take a product perspective instead of a material perspective, and the aim is to set up closed-loops in which the complexity and functionality of a product are conserved for as long as possible, rather than breaking a product down into 
its basic materials after each use cycle. Many individual countries have adopted policies and tax measures that incentivize circular products and business models. The transition to a circular economy is not an easy, gradual evolution; it requires a profound change in the way we live, travel, work, and do business. To move forward with the transition, there is a need for different types of products and services, a new legislative framework, and a stronger interaction between stakeholders. Furthermore, the implementation of circular economy needs a robust interaction of different actors across value chains and sectors.

The research society and practitioners have joined the transition and grasped the opportunity of moving toward more sustainable and environmentally friendly businesses. In Finland, numerous researches and projects have been carried out in the field of circular economy and it has been a popular research subject. In this essence, the current study has investigated the circular economy movement among researchers and practitioners to get a deeper knowledge on how different aspects of circular economy have been taken into account.

In this article, published research projects and outputs in the form of articles (journal, reviews, and conference papers), reports, and book chapters have been reviewed over two time-periods: 2000-2016 and 2017-2020. The "hot topics" of circular economy research in Finland in 2000-2016 period were biomass and wood waste, reuse, repair and remanufacture, energy from waste, waste management, and industrial waste. In 2017-2020, the same topics were still researched with an additional focus on metal and mining waste. The biggest increase rate of interest was on microplastics, plastic waste, circular economy concept, sharing economy, and eco-design. However, in most of these topics, the absolute number of articles is still among the lowest.

Considering the priorities of current legislation and policies in Europe and Finland, and comparing them with the topics of high interest, it can be noted that there is a strong link between legal drivers and environmental considerations for movement toward circular economy. Sitra's roadmap to circular economy in Finland had an undeniable impact on scientist' and practitioners' interests in the focus areas highlighted by the report. Stricter environmental standards, extended producer responsibility, and higher recycling targets are often incentives to shift to a society that is more circular. In many fields, such as microplastic and biomass, and wood waste research, Finnish researchers has responded to the need of the society to develop new ways to be more circular.

The trend analysis shows that all topics have experienced positive increase rates, therefore, it can be summarized that sustainability is valued in all fields of research and practice, are the responses are appropriate to green policies. However, there is still a gap in the research in the fields that are related to upstream concepts such as design for environment, service-based society, and re-thinking/re-establishing business models. Here the role of design-for-repair, design-for-recycle, and design-for-remanufacture will rise as a vital solution of moving toward circular economy. Waste policies and product designs should be allied, in other to facilitate circular material flows, in support of circular business creation.

This study is not exempt from limitations, selection of keywords and search terms may have led to the omission of some studies. Moreover, there might be publications in Finnish language which are not included in this study. There also could have been actions that were not published; therefore, they were unattainable by this review. This study used a quantitative approach; therefore, each article is valued as one. However, there might be some studies that are more relevant and influential than others. Furthermore, the selection of databases may have resulted in exclusion of some publications from this study. For future studies searching a wider selection of databases (such as Web of Science) could be recommended.

Author Contributions: Conceptualization: A.H., J.Y.-M., and E.P.; methodology: A.H., J.Y.-M., and E.P.; data collection: A.H.; formal analysis: A.H.; writing: original draft preparation: A.H.; writing: review and editing: A.H., J.Y.-M., and E.P.; supervision: J.Y.-M. and E.P.; project administration and funding acquisition: E.P. All authors have read and agreed to the published version of the manuscript. 
Funding: This research was funded by the Academy of Finland provided for the TRANSCIRC project (nro 310407).

Acknowledgments: The authors acknowledge the funding of the Academy of Finland provided for the TRANSCIRC project (nro 310407).

Conflicts of Interest: The authors declare no conflict of interest.

\section{Research Highlights:}

- $\quad$ The influence of circular economy policies and national strategies on research trends is noticeable.

- Recycling-based interpretation of circular economy seems to dominate over the waste preventionbased approaches.

- Design for environment and sharing economy should be prioritized more in research.

\section{References}

1. Giusti, L. A review of waste management practices and their impact on human health. Waste Manag. 2009, 29, 2227-2239. [CrossRef] [PubMed]

2. European Commission. Circular Economy Stakeholder Platform, Circular Economy Stakeholder Conference: Success Stories and New Challenges. Brussels Belgium. 2019. Available online: https://circulareconomy.europa.eu/platform/en/node/1301 (accessed on 26 October 2020).

3. European Commission. Communication from The Commission to The European parliament, The Council, The European Economic and Social Committee and the Committee of the Regions, The European Green Deal; European Commission: Brussels, Belgium, 2019.

4. Ghisellini, P.; Cialani, C.; Ulgiati, S. A review on circular economy: The expected transition to a balanced interplay of environmental and economic systems. J. Clean. Prod. 2016, 114, 11-32. [CrossRef]

5. Lieder, M.; Rashid, A. Towards circular economy implementation: A comprehensive review in context of manufacturing industry. J. Clean. Prod. 2016, 115, 36-51. [CrossRef]

6. Korhonen, J.; Honkasalo, A.; Seppälä, J. Circular Economy: The Concept and its Limitations. Ecol. Econ. 2018, 143, 37-46. [CrossRef]

7. European Commission. Closing the Loop—An EU Action Plan for the Circular Economy; European Commission: Brussels, Belgium, 2015. [CrossRef]

8. Finland Ministry of Environment. Available online: http://www.ym.fi/en-US/The_environment/Circular_economy (accessed on 10 October 2017).

9. Sitra, Leading the Cycle-Finnish Road Map to a Circular Economy 2016-2025. 2016. Available online: www.sitra.fi (accessed on 10 October 2017).

10. Ministry of the Environment Finland. From Recycling to a Circular Economy, National Waste Plan to 2023. 2018. Available online: https: / /ym.fi/en/national-waste-plan (accessed on 21 March 2019).

11. European Commission. Communication from The Commission to The European parliament, The Council, The European Economic and Social Committee and the Committee of the Regions, A European Strategy for Plastics in a Circular Economy. 2018. Available online: https:/ / eur-lex.europa.eu/resource.html?uri=cellar:2df5d1d2-fac7-11e7-b8f5-01aa75ed71a1.0001.02/DOC_ $1 \&$ format=PDF (accessed on 1 December 2018).

12. European Commission. Communication from the Commission to the European Parliament, the Council, the Economic and Social Committee and the Committee of the Region on the Implementation of the Circular Economy Package: Options to Address the Interface between Chemical, Product, and Waste Legislation. 2018. Available online: https://ec.europa.eu/docsroom/ documents/27321/attachments/1/translations/en/renditions/native (accessed on 1 December 2018).

13. European Commission. Communication from the Commission to the European parliament, the Council, the European Economic and Social Committee and the Committee of the Regions, on a Monitoring Framework for The Circular Economy. 2018. Available online: https:/ / eur-lex.europa.eu/legal-content/EN/TXT/PDF/?uri=CELEX:52018DC0029\&from=EN (accessed on 1 December 2018).

14. European Commission. European Commission, Report on Critical Raw Materials and the Circular Economy. 2018. Available online: https: / / ec.europa.eu/docsroom/documents/27327 (accessed on 1 November 2020).

15. European Commission. Communication from The Commission to The European Parliament, The Council, The European Economic and Social Committee and the Committee of the Regions, A New Circular Economy Action Plan for a Cleaner and More Competitive Europe; European Commission: Brussels, Belgium, 2020.

16. Armann-keown, V.; Patterson, L. Content analysis in library and information research: An analysis of trends. Libr. Inf. Sci. Res. 2020, 42, 101048. [CrossRef]

17. Alnajem, M.; Mostafa, M.M.; El Melegy, A.R. Mapping the first decade of circular economy research: A bibliometric network analysis. J. Ind. Prod. Eng. 2021, 38, 29-50. [CrossRef]

18. Lopes, J.; Farinha, L. Industrial symbiosis in a circular economy: Towards firms, sustainable competitive advantage. Int. J. Mechatron. Appl. Mech. 2019, 5, 206-220. [CrossRef]

19. Luis, E.C.; Celma, D. Circular economy. A review and bibliometric analysis. Sustainability 2020, 12, 6381. [CrossRef] 
20. Ruiz-Real, J.L.; Uribe-Toril, J.; Valenciano, J.D.P.; Gázquez-Abad, J.C. Worldwide research on circular economy and environment: A bibliometric analysis. Int. J. Environ. Res. Public Health 2018, 15, 2699. [CrossRef]

21. Choi, H.S.; Lee, W.S.; Sohn, S.Y. Analyzing research trends in personal information privacy using topic modeling. Comput. Secur. 2017, 67, 244-253. [CrossRef]

22. Teuber, L.; Osburg, V.S.; Toporowski, W.; Militz, H.; Krause, A. Wood polymer composites and their contribution to cascading utilization. J. Clean. Prod. 2016, 110, 9-15. [CrossRef]

23. Väisänen, T.; Haapala, A.; Lappalainen, R.; Tomppo, L. Utilization of agricultural and forest industry waste and residues in natural fiber-polymer composites: A review. Waste Manag. 2016, 54, 62-73. [CrossRef] [PubMed]

24. Kirchherr, J.; Reike, D.; Hekkert, M. Conceptualizing the circular economy: An analysis of 114 definition. Resour. Conserv. Recycl. 2017, 127, 221-232. [CrossRef]

25. Feng, Z.; Yan, N. Putting a circular economy into practice in China. Sustain. Sci. 2007, 2, 95-101. [CrossRef]

26. Hideto, S.S.; Yasuhiro, Y.; Misuzu, H.; Takigami, H.; Takahashi, S.; Tomoda, K.; Victoria, M.; Wejchert, J.; Aldo, T.S.; Douvan, R.; et al. International comparative study of 3R and waste management policy developments. Mater Cycles Waste Manag. 2011, 13, 86-102. [CrossRef]

27. Reh, L. Process engineering in circular economy. Particuology 2013, 11, 119-133. [CrossRef]

28. Potting, J.; Hekkert, M.; Worrell, E.; Hanemaaijer, A. Circular Economy: Measuring Innovation in the Policy Report; PBL Netherlands Environmental Assessment Agency: The Hague, The Netherlands, 2017.

29. European Parliament. Towards a Circular Economy—Waste Management in the EU; STOA—Science and Technology Options Assessment: Brussels, Belgium, 2017. [CrossRef]

30. European Commission. Raw Materials Information System (RMIS), Policies and Definitions. 2020. Available online: http: // https / /rmis.jrc.ec.europa.eu/?page=policies-and-definitions-2d5b5e.2020 (accessed on 21 March 2019).

31. Spooren, J.; Binnemans, K.; Björkmalm, J.; Breemersch, K.; Dams, Y.; Folens, K.; González-Moya, M.; Horckmans, L.; Komnitsas, K.; Kurylak, W.; et al. Near-zero-waste processing of low-grade, complex primary ores and secondary raw materials in Europe: Technology development trends. Resour. Conserv. Recycl. 2020, 160, 104919. [CrossRef]

32. European Commission. Critical Raw Materials Resilience: Charting a Path towards Greater Security and Sustainability. Brussels. 2020. Available online: https:/ / eur-lex.europa.eu/legal-content/EN/TXT/PDF/?uri=CELEX:52020DC0474\&from=EN (accessed on 21 March 2019).

33. Ylä-mella, J.; Pongrácz, E. Drivers and Constraints of Critical Materials Recycling: The Case of Indium. Resources 2016, 5, 34. [CrossRef]

34. Leal, W.F.; Saari, U.; Fedoruk, M.; Iital, A.; Moora, H.; Klöga, M.; Voronova, V. An overview of the problems posed by plastic products and the role of extended producer responsibility in Europe. J. Clean. Prod. 2019, 214, 550-558. [CrossRef]

35. Waller, C.L.; Griffiths, H.J.; Waluda, C.M.; Thorpe, S.E.; Loaiza, I.; Moreno, B.; Pacherres, C.O.; Hughes, K.A. Microplastics in the Antarctic marine system: An emerging area of research. Sci. Total Environ. 2017, 598, 220-227. [CrossRef]

36. Scopetani, C.; Esterhuizen-Londt, M.; Chelazzi, D.; Cincinelli, A.; Setälä, H.; Pflugmacher, S. Self-contamination from clothing in microplastics research. Ecotoxicol. Environ. Saf. 2020, 189. [CrossRef]

37. Kummu, M.; de Moel, H.; Porkka, M.; Siebert, S.; Varis, O.; Ward, P. Lost food, wasted resources: Global food supply chain losses and their impacts on freshwater, cropland, and fertiliser use. Sci. Total Environ. 2012, 438, 477-489. [CrossRef] [PubMed]

38. United Nations, Food and Agriculture Organization of United Nations. 2020. Available online: http://www.fao.org/platformfood-loss-waste/flw-data/en/ (accessed on 10 November 2020).

39. Katajajuuri, J.-M.; Silvennoinen, K.; Hartikainen, H.; Heikkilä, L.; Reinikainen, A. Food waste in the Finnish food chain. J. Clean. Prod. 2014, 73, 322-329. [CrossRef]

40. European Commission. The National Finnish Food Waste. 2019. Available online: https://ec.europa.eu/food/sites/food/files/ safety/docs/fw_eu-platform_20191212_flw_pres_minna.pdf (accessed on 11 May 2019).

41. Berkhout, F.; Smith, A.; Stirling, A. Socio-technological regimes and transition contexts. Syst. Innov. Transit. Sustain. Theory Evid. Policy 2004, 44, 48-75.

42. Jurgilevich, A.; Birge, T.; Kentala-Lehtonen, J.; Korhonen-Kurki, K.; Pietikäinen, J.; Saikku, L.; Schösler, H. Transition towards Circular Economy in the Food System. Sustainability 2016, 8, 69. [CrossRef]

43. Cordell, D.; Drangert, J.-O.; White, S. The story of phosphorus: Global food security and food for thought. Glob. Environ. Chang. 2009, 19, 292-305. [CrossRef]

44. Kabbe, C.; Remy, C.; Kraus, F. Review of Promising Methods for Phosphorus Recovery and Recycling from Wastewater; International Fertiliser Society: London, UK, 2015; Available online: www.fertiliser-society.org (accessed on 16 January 2019).

45. Nättorp, A. European Sustainable Phosphorus Platform (ESPP). 2015. Available online: https://phosphorusplatform.eu/scopein-print/scope-in-press/1449-phosphorus-recovery-and-recycling-in-japan (accessed on 31 January 2019).

46. Buckwell, A.; Nadeu, E. Nutrient Recovery and Reuse (NRR) in European Agriculture A Review of the Issues, Opportunities, and Actions; RISE Foundation: Brussels, Belgium, 2016. 